\title{
On the Path of Legal Psychology Education in Terms of the Historical Background of the Formation of Chinese Legal Psychology
}

\author{
Yin Hai \\ Jiangxi Institute of Fashion Technology
}

\author{
Cao Hua \\ Jiangxi Institute of Fashion Technology
}

\begin{abstract}
The legal consciousness of college students plays an important role in legal quality in the construction of our socialist country under the rule of law. At present, it is crucial for university students to have basic knowledge of legal psychology and form good legal faith to improve legal consciousness. This paper, starting from the analysis of the causes of college students' lack of legal psychology, puts forward some measures of setting up the legal consciousness of college students to lay the mass foundation of socialist developing countries and improve college students' legal concept.
\end{abstract}

Keywords-Legal Psychology; Legal Education; Current Situation; Measures

\section{INTRODUCTION}

Legal psychology is closely related legal consciousness that we often speak about which is the infancy of legal consciousness and it is the experience and feelings that a person have from their own practical experience under the socialist culture background. That is to say, without the infancy stage of legal psychology, college students will not have the legal concept. College students are at the stage of cultivating and perfecting their outlook on life and values, so strengthening college students' legal consciousness plays a very important role in structural elements of the legal consciousness of the whole society. As college students will have the sense of gap due to the bad temptation of the society as well as the bad influence of all kinds of unfair phenomena during the sharp transformation period of the society which is caused by the conflict and contradiction between reality and ideals thus causing incorrect legal psychology and repulsion to law, we should use psychological guidance to help college students establish correct legal consciousness.

\section{THE CURRENT SITUATION OF COLLEGE STUDENTS' LEGAL EDUCATION UNDER THE BACKGROUND OF THE FORMATION OF CHINESE LEGAL PSYCHOLOGY}

In real life, college students' psychological condition does not often conform to their behavior badly. When personal interests have conflict with the interests of the country and the society, they will behave blindly and ignore the law, which means that their legal mind is not mature. The performance of psychological immaturity will be analyzed specifically below:

\section{A. Traditional Lack of Legal Psychology}

The traditional feudal thoughts are deeply rooted in our country and China's feudal society is never lack of privileges and tyranny whose hangover is affecting the contemporary young people. In addition, "the ritual" in the traditional society occupies an important position. However, the law only plays a supplementary role. For a long time, people seldom depend on law or make use of it. As a result, their legal mind is not mature.

\section{B. The Influence of Legal Status}

In the process of promoting the modernization of legal system, many problems are appeared in our country, which have certain influence on the education of college students' legal psychology. Since the foundation of our country, the law has been amended for several times which lacks comparative stability. And for the scientific rationality of some legislative links has yet to be proven, the principle of law appears to be challenged. Moreover, due to conflicts between some laws, even unconstitutional act will become invalid. This kind of legal vacancy phenomenon causes people to lack legal psychology. At the same time, with the phenomenon of "power taking over law" and "power suppressing law" sometimes occurring, the authority of law has been challenged frequently, which makes people doubt the principle of "everyone is equal in front of law". Finally, our country's judicial system also needs to be improved, as judicial injustice phenomenon makes people lost confidence in law not to mention setting up legal psychology.

\section{Imperfect Legal Education Course in University}

Currently, college education focuses on professional knowledge while neglects the cultivation and strengthening of legal concept. Even if there are legal education courses, they are only limited to teaching pure legal theory. On one hand, legal theory is often badly disconnected with real practice. On the other hand, the setting of legal education courses is not persistent which lacks long-term planning. Therefore, the training of college students' legal psychology can not form a system.

\section{The Subjective Factors of College Students}

As the college students of new generation are mostly only-one-child and they are almost doing very well and seldom experience any setbacks in their daily lives, their outlooks on things just stay in the perceptual stage. What is 
more, yield to the temptation of materialism and the influence of the social bad phenomenon, their outlooks on life and values are affected unconsciously. Besides, the pressure from their studies which makes them only pay attention to their own specialized courses and final grades and neglect the improvement of their legal concept. All these contribute to the more impossibility of the setting-up of legal psychology

\section{SOME EFFECTIVE MEASURES TO CULTIVATE COLLEGE STUDENTS' LEGAL PSYCHOLOGY}

As College students' outlooks on life and values gradually form, the cultivation of their legal psychology is a long-term and complicated process of osmosis. We must start from the real situation of college students to find some effective measures to cultivate their legal psychology and to strengthen their legal concept and legal consciousness.

\section{A. Cultivating College Students' Rights Consciousness}

China's legal system lacks protecting the exercise of citizen rights, but attaches great importance to the construction of legal authority and national force. That law is the law of people can only be embodied as long as to cultivate citizens' rights consciousness, so that citizens' affinity and trust to law can be enhanced. Furthermore, the enhancement of people's rights consciousness is beneficial to strengthen the legal identity and set up their legal psychology. So as for College students, to cultivate college students' rights consciousness, we should first make them clear about the scope of their rights and obligations and realize the unity of rights and obligations which means without obligation there is no right to enjoy and exercise. Those who are able to use the legal weapon to protect their legal rights and fully recognize that the law can maintain social order and promote the social justice are really able to set up their own legal psychology.

\section{B. Enhance Law-Abiding Consciousness}

The outer performance of the setting up of legal psychology is behaving by law, while the law-abiding consciousness is the most important standpoint of legal psychology. Law-abiding consciousness not only requires people to obey the law, but also demands people's psychological shift from "do not dare to break the law" to "should not break the law", which means that people see law-abidance as their own duties and good moral requirements, realizing their taking initiative to regard lawabidance as a moral requirement but not the passive one under national force deterrence. Realizing the change successfully can not rely on the national force but count on the education and management of the school. So that schools should make the legal education penetrate into all aspects of daily teaching and management to affect the students in all aspects of school life unconsciously and to create a good environment for cultivating college students' legal psychology. In addition, schools must be managed by law, which is the new requirement the 18th session of National People's Congress of the party puts forward on schools' legal construction which requires schools to fully respect students' rights, to protect students' rights to know schools' every policy as well as students' rights to participate in school affairs by democratic means such as in the way of hearing and the parent-teacher conference when making school regulations and disciplines. At the same time, schools should strictly investigate and punish students' violation of school's regulations and rules in accordance with the rule to achieve the equality before law, thus to make the students who broke the rules or the law repent and mend their way thoroughly.

\section{Experience the Value of Law}

Value experiencing is the basic way to cultivate college students' legal psychology. In the process of cultivating the legal psychology, we must insist on students' initiative to experience the value of the law and identify with the law in person from the perspective of practice. Legal practice is the foundation of legal value experience and legal practical course is the basic link of cultivating legal psychology. For acquisition of knowledge, no experience is deeper than direct experience. Adding legal practice course can enhance students' perceptual sense of law and its value to promote students' rational evaluation on the values of law thus laying the foundation for legal psychology. For example, we can ask students to attend the court trial process to experience the role of law in maintenance of order and safeguarding rights; we can focus on helping students understand the legislation motive and principle through the analysis and discussion of typical cases; we can also guide students to concern about the hot spots of our society, analyze the causes from the perspective of legal theory and try to think about how to use legal weapon to solve the problem. Students' main body status is the ideological basis and means of protection of legal value experience. In the legal education courses, students should be treated as the "main body" of the classroom which improves students' ability of practice and enhance their identity with the law through application to law and consciously abide by the law. We should know the setting up of legal psychology is a systematic project which needs pushing step by step without rush. With the formation of legal emotion as the inner base, we should cultivate and set up college students' legal psychology in a correct way by improving the legal environment of our society to improve the legal education of college students and create a harmonious atmosphere for the cultivation of college students' legal psychology.

\section{CONCLUSIONS}

In the future, the legislation of our country must adhere to the basic conditions of legal implementation. We should gradually establish a perfect legal system on the basis of the basic conditions that the social life and law require so as to provide the foundation soil for law. Full preparation should be made for college students' legal consciousness, legal psychology and the setting up of good legal faith by joint efforts of the state, society, schools and individuals.

\section{REFERENCES}

[1] Chuang Jin : "Choice in Culture Collision : the Change of Chinese traditional ritual culture in modern times" "The contemporary law",2009, 6

[2] Liu Riming: "Legal positivism and euthanasia of legal philosophy", "Journal of Tongji university" (Social science edition) 2007,5

[3] Liu HuiPin. Mental set theory of public law and law education [J]. Probe, 2001 01:56-59. 
[4] Chen Zaisheng. Discuss about the psychological state of college students' legal system and legal system education $[\mathrm{J}]$. Journal of zhangzhou normal university (philosophy and social sciences edition), 2001, 95:95-98.

[5] Li Xiaohong. Discuss how to permeate the legal system education in the mental health education [J]. Journal of vocational technology, $2011,10,62$

[6] Li Qiaoling . Theory of contemporary university students' illegal crime psychology and education of legal system [J]. Journal of law and economic (below the ten-day), 2009, 09: 39-40.

[7] "Legal psychology discipline construction and development seminarl" minutes - legal psychology professional committee of Chinese psychological society $[\mathrm{J}]$. Journal of political science and law, 2003 01:97-98.

[8] Liu Yunsheng. The relationship between the factors theory of harmonious society legal system and psychological factors [J]. Journal of Hebei Radio and Television University, 2007 and practices: 35 to 37
[9] Zhang Yan An Bin. From the university student crime psychological effective way to explore the university legal education [J]. Journal of education and career, 2010 01:174-175.

[10] Deng YongDong. Follow the psychological laws pays special attention to the warning education legal system [J]. Journal of army political work theory research, 2014, 11:77-79.

[11] The Chinese psychological society legal psychology held legal psychology association professional committee, Tianjin public security judicial officer mental health seminars news [J]. Science of social psychology, 2005, 127:127-128.

[12] Liao DengJie. FaZhiKe strengthening mental health education in practice $[\mathrm{J}]$. Journal of new curriculum (research), 2009 and practices: 103.

[13] Li Yin. Analyses the contemporary university student's crime psychology and education of legal system $[\mathrm{J}]$. Journal of century bridge, 2008): $59-60+65$. 